\title{
THE OCCURRENCE OF LYMPHOCYTE ANTIGENS ON BOAR SPERMATOZOA
}

\author{
F. JÍLEK AND L. VESELSKÝ \\ Laboratory of Animal Genetics, Czechoslovak Academy of Sciences, \\ Libéchov, Czechoslovakia
}

(Received 27th March 1972, accepted 19th May 1972)

As on other cell types, some histocompatibility antigens have recently been found on spermatozoa. Vojtíšková (1969), and Vojtišková, Poláčková \& Pokorná (1969) revealed the presence of some H-2 antigens on mouse spermatozoa by using antibody absorption, indirect immunofluorescence and presensitization of recipients with sperm cells to specific skin grafts. Similarly, Goldberg, Aoki, Boyse \& Bennett (1970) demonstrated the presence of H-2 antigens and later of H-Y antigen (Goldberg, Boyse, Bennett, Scheid \& Carswell, 1971) on mouse spermatozoa by means of a cytotoxic test applied to the spermatozoa. Fellous \& Dausset $(1970)$ have published similar results concerning the detection of HL-A antigens on human spermatozoa. Singal, Berry \& Naipaul (1971), however, detected HL-A substances in seminal plasma. These antigens on spermatozoa may, therefore, be a phenotypic demonstration of the sperm genome or may be absorbed onto spermatozoa from another source.

This brief report presents results of a study of leucocyte antigens on boar spermatozoa by means of absorption and inhibition tests.

Antilymphocyte sera with cytotoxic activity obtained after the immunization of pigs with lymphocytes from lymph nodes, whole blood (leucocyte part included), and skin grafts were used in the study. From thirty-five antisera prepared in this way, four were chosen (Nos. 56, 58, 53 and 55), each showing different specificity as determined by testing in a lymphocyte panel of thirty unrelated individuals. A lymphocytotoxic antiserum, Ap, detecting A antigen common to erythrocytes and lymphocytes was also used (Simon \& Hruban, 1972). In antisera with a high antibody titre, this ratio was modified into a working titre of $1: 32$.

For testing, lymphocytes separated from peripheral blood (Simon \& Hruban, 1971) and a macrocytotoxic test (Gorer \& O’Gorman, 1956) were used.

The four chosen antisera and Ap antiserum were absorbed by ejaculated spermatozoa from four boars (A-1, A-80, L-5 and L-10) chosen out of a group of ten boars according to preliminary typing of their lymphocytes by these antisera. Individuals whose lymphocytes reacted positively to the given antiserum are referred to in the text as 'positive donors', and individuals whose lymphocytes did not react to the antisera as 'negative donors'.

The ejaculated spermatozoa were washed three times with phosphatebuffered saline ( $\mathrm{pH} \mathrm{7.4)}$ and after final centrifugation at $5000 \mathrm{rev} / \mathrm{min}(4200 \mathrm{~g})$ for $20 \mathrm{~min}$, the antisera were absorbed at a volume ratio of $1: 1$ (approximately 
$1 \times 10^{9}$ spermatozoa to $1 \mathrm{ml}$ of antiserum) by packed spermatozoa for $1 \mathrm{hr}$ at $37^{\circ} \mathrm{C}$. The antisera were absorbed two to four times (Table 1). Absorptions of spermatozoa from positive and negative donors were always carried out in parallel, and the decrease of cytotoxic antiserum activity was ascertained after each absorption.

Inhibition tests using some body fluids (seminal plasma, blood serum and

TABLE 1

RESULTS OF ABSORPTIONS OF LYMPHOGYTOTOXIC ANTIBODIES BY BOAR SPERMATOZOA

\begin{tabular}{|c|c|c|c|c|c|c|}
\hline \multirow[b]{2}{*}{$\begin{array}{c}\text { Lymphocytotoxic } \\
\text { antisera }\end{array}$} & \multirow{2}{*}{$\begin{array}{c}\text { Working titre } \\
\text { of antisera before } \\
\text { absorption }\end{array}$} & \multicolumn{4}{|c|}{ Antisera titres after absorptions } & \multirow[b]{2}{*}{$\begin{array}{c}\text { No. of } \\
\text { absorptions }\end{array}$} \\
\hline & & $\begin{array}{c}A 1 \\
(A p, 56) *\end{array}$ & $\begin{array}{c}A 80 \\
(A p, 58)^{*}\end{array}$ & $\begin{array}{c}L 5 \\
(53,55)^{*}\end{array}$ & $\begin{array}{c}L 10 \\
(53,55)^{*}\end{array}$ & \\
\hline $\begin{array}{l}\text { Ap } \\
56 \\
58 \\
53 \\
55\end{array}$ & $\begin{array}{r}8 \\
32 \\
32 \\
32 \\
32\end{array}$ & $\begin{array}{l}0 \\
4 \\
4 \\
8 \\
8\end{array}$ & $\begin{array}{l}0 \\
8 \\
0 \\
8 \\
8\end{array}$ & $\begin{array}{l}4 \\
8 \\
4 \\
0 \\
2\end{array}$ & $\begin{array}{l}4 \\
8 \\
2 \\
0 \\
2\end{array}$ & $\begin{array}{l}2 \\
4 \\
4 \\
4 \\
4\end{array}$ \\
\hline
\end{tabular}

* Sperm donor and (in parentheses) lymphocyte type of sperm donor.

TABLE 2

INHIBITIONS OF CYTOTOXIC REACTIONS OF ANTIBODIES TO LYMPHOCYTES OF POSITIVE DONORS BY SOME BODY FLUIDS OF BOARS

\begin{tabular}{|c|c|c|c|c|c|c|c|}
\hline \multirow{2}{*}{$\begin{array}{l}\text { Donor of } \\
\text { body } \\
\text { fluids }\end{array}$} & \multirow{2}{*}{$\begin{array}{l}\text { Lymphocyte } \\
\text { type of } \\
\text { donors }\end{array}$} & \multirow{2}{*}{$\begin{array}{l}\text { Body fluids } \\
\text { used for } \\
\text { inhibitions }\end{array}$} & \multicolumn{5}{|c|}{ Inhibited antisera } \\
\hline & & & $A p$ & 56 & 58 & 53 & 55 \\
\hline A 1 & Ap, 56 & $\begin{array}{l}\text { Saliva } \\
\text { Seminal plasma } \\
\text { Blood serum }\end{array}$ & $\begin{array}{l}1: 32^{*} \\
1: 2^{*} \\
1: 4^{*}\end{array}$ & $\begin{array}{l}- \\
-\end{array}$ & $\bar{z}$ & $\bar{z}$ & $\begin{array}{l}- \\
-\end{array}$ \\
\hline A 80 & Ap, 58 & $\begin{array}{l}\text { Saliva } \\
\text { Seminal plasma } \\
\text { Blood serum }\end{array}$ & $\begin{array}{l}1: 32^{*} \\
1: 4^{*} \\
1: 4^{*}\end{array}$ & $\begin{array}{l}- \\
-\end{array}$ & $\begin{array}{l}z \\
z\end{array}$ & $\bar{z}$ & $=$ \\
\hline L 5 & 53,55 & $\begin{array}{l}\text { Saliva } \\
\text { Seminal plasma } \\
\text { Blood serum }\end{array}$ & $\begin{array}{l}- \\
-\end{array}$ & $\begin{array}{l}- \\
-\end{array}$ & $\begin{array}{l}- \\
-\end{array}$ & $\overline{-}$ & $\begin{array}{l}+ \\
+ \\
+\end{array}$ \\
\hline L 10 & 53,55 & $\begin{array}{l}\text { Saliva } \\
\text { Seminal plasma } \\
\text { Blood serum }\end{array}$ & $\overline{-}$ & $\begin{array}{l}- \\
- \\
-\end{array}$ & $\begin{array}{l}- \\
-\end{array}$ & $\frac{-}{\mathrm{N}}$ & $\begin{array}{l}+ \\
+ \\
+\end{array}$ \\
\hline
\end{tabular}

$\mathrm{N}=$ Undiluted state of inhibition fluids. + , Positive results of inhibition tests with concentrated inhibition fluids. -, Negative results of inhibition tests.

* Degree of dilution of inhibition fluids still giving positive results in inhibition tests.

saliva) of positive donors and negative donors were carried out with all antisera. Two drops of each antiserum dilution were incubated with two drops of saliva, blood serum or seminal plasma at $37^{\circ} \mathrm{C}$ for $1 \mathrm{hr}$. The remainder of the procedure was identical to the routine lymphocytotoxic test. If positive results of inhibition tests were already found in undiluted antiserum, the titration was carried out in reverse. Two drops of each dilution of the inhibition fluids were incubated with two drops of antiserum. In control inhibition tests, the seminal 
plasma, blood serum or saliva were replaced by physiological saline containing $10 \%$ calf serum.

The inhibitions of Ap antisera in the cytotoxic reaction by the seminal plasma, blood serum and saliva of donors with their own lymphocytes and also with lymphocytes from other positive donors were positive, while the saliva, blood serum and seminal plasma of negative donors did not change the activity of Ap antiserum in inhibition tests (Table 2). The activity of Antiserum 53 was inhibited only by the blood serum of positive donors, all inhibition tests were negative with Antisera 56 and 58 (Table 2) and with Antiserum 55, the results of inhibition tests were doubtful. To make the effects of inhibition stronger, concentrated material was used. Seminal plasma, blood serum and saliva were dialysed against several portions of distilled water during $24 \mathrm{hr}$ at $4^{\circ} \mathrm{C}$ and then freeze dried. The resulting material was dissolved in physiological saline at a maximum concentration which still allowed it to be used in inhibition tests. (Saliva was concentrated thirtyfold, seminal plasma tenfold and blood serum fivefold compared with the original concentration.) Inhibition tests were repeated with the above-mentioned material in all cases where the original results were negative or doubtful. Antigenic substances detected by Antiserum 55 proved to be present in the saliva, seminal plasma and blood serum of positive donors (Table 2). In all other instances, the results of inhibition tests with concentrated body fluids were the same as with body fluids in their original concentrations.

After the second absorption by spermatozoa, Ap antiserum lost all its cytotoxic activity, while non-specific absorption activity by negative donors only decreased by one degree of dilution (Table 1). Nevertheless, substances determined by this antiserum were found by means of inhibition tests in a great number of saliva, blood serum and seminal plasma samples (Table 2). The ability of spermatozoa of positive donors to absorb Ap antibodies from the antiserum was approximately twice as great as in other antisera. Thus, it is probable that antigenic substance detectable by anti-Ap lymphocytotoxic antibodies originate from the seminal plasma, as in the case of erythrocyte A substance on boar spermatozoa (Matoušek, Dostál \& Fulka, 1966), or that the amount of these antigens on spermatozoa is at least considerably increased from this source.

The Antisera 53, 55 and 56 were absorbed by spermatozoa from positive donors in approximately half intensity (Table 1 ). With the increasing number of absorptions, some non-specific absorption activity was shown after absorption with spermatozoa from negative donors. We may assume from the results that substances detected by these antisera are present on boar spermatozoa, although probably in small numbers. Antiserum 58 lost its activity after four absorptions by material from positive donors (Table 1), but the non-specific absorption activity in absorptions with spermatozoa from negative donors was considerable. To explain these reactions, various factors can be considered.

Both in absorption and inhibition tests, no differences were found in the reactivity of antisera with lymphocytes of individual positive donors.

The results of the present study suggest that at least some lymphocyte antigens, which are detectable in cytotoxic tests, are present on boar sperma- 
tozoa. Considering the high number of spermatozoa necessary for absorption or decrease in the titre of a given antibody, we may assume that these antigens are only present on boar spermatozoa in very small amounts. From the results of inhibition tests, it is improbable that all these antigens originate from seminal plasma, but this cannot be regarded as proof of their genome expression on the sperm membrane.

We thank Dr J. Hojný, Dr J. Hradecký, Dr M. Simon and Dr V. Hruban for offering the cytotoxic antisera.

\section{REFERENCES}

Fellous, M. \& Dausset, J. (1970) Probable haploid expression of HL-A antigens on human spermatozoon. Nature, Lond. 225, 191.

Goldberg, E. H., Aoki, T., Boyse, E. A. \& Bennett, D. (1970) Detection of H-2 antigens on mouse spermatozoa by the cytotoxicity test. Nature, Lond. 228, 570 .

Goldberg, E. H., Boyse, E. A., Bennett, D., Scheid, M. \& Garsweld, E. A. (1971) Serological demonstration of H-Y (male) antigen on mouse sperm. Nature, Lond. 232, 478.

Gorer, P. A. \& O'Gorman, P. (1956) The cytotoxic activity of isoantibodies in mice. Transplantn Bull. $3,142$.

Matoušex, J., Dostál, J. \& Fulka, J. (1966) Antigenicity and polymorphism of the seminal vesicle fluid in boars. Proc. 10th Eur. Conf. Anim. Blood Grps Biochem. Polymorphisms (Paris, 1966), p. 523. Institut National de la Recherche Agronomique, Paris.

Simon, M. \& Hruban, V. (1971) Lymphocyte typing in pigs: evidence for antigen L 1. Anim. Blood Grps Biochem. Genet. 2, 95.

Simon, M. \& Hruban, V. (1972) Cytotoxic action of pig anti-A erythrocyte antibodies. Vox Sang. (in press).

Singal, D. P., Berry, R. \& Naipaul, N. (1971) HL-A inhibiting activity in human seminal plasma. Nature (New Biology), 233, 61.

Vojtí̌́xoví, M. (1969) H-2 antigens on mouse spermatozoa. Nature, Lond. 222, 1293.

Vojtí̌Ková, M., PoláčKová, M. \& Pokorná, Z. (1969) Histocompatibility antigens on mouse spermatozoa. Folia biol., Praha, 15, 322. 